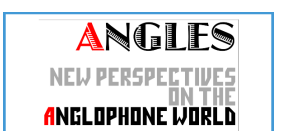

ANELOPHONE WORLI

\section{Angles}

New Perspectives on the Anglophone World

1 | 2015

Brevity is the soul of wit

\title{
Three Little Words and the Critical Argument of The Best Show on WFMU
}

\section{Thomas Britt}

\section{(2) OpenEdition \\ 1 Journals}

\section{Electronic version}

URL: https://journals.openedition.org/angles/2118

DOI: $10.4000 /$ angles. 2118

ISSN: 2274-2042

\section{Publisher}

Société des Anglicistes de l'Enseignement Supérieur

\section{Electronic reference}

Thomas Britt, "Three Little Words and the Critical Argument of The Best Show on WFMU", Angles [Online], 1 | 2015, Online since 01 November 2015, connection on 07 June 2022. URL: http:// journals.openedition.org/angles/2118; DOI: https://doi.org/10.4000/angles.2118

This text was automatically generated on 7 June 2022.

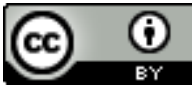

Angles est mise à disposition selon les termes de la Licence Creative Commons Attribution 4.0 International. 


\title{
Three Little Words and the Critical Argument of The Best Show on WFMU
}

\author{
Thomas Britt
}

1 Brevity is not the first word that comes to mind when thinking of comedian Tom Scharpling's The Best Show on WFMU. ${ }^{1}$ A listener-supported show on an independent, free form radio station, The Best Show was on the air from 2000 to 2013 for three hours weekly. In a media age saturated with podcasts hoping to keep a listener engaged for twenty minutes, The Best Show defined long-form radio comedy for more than a decade as its popularity grew internationally through physical releases, streams and downloads.

2 Scharpling often summarized the content of his show as "three hours of Mirth, Music, and Mayhem". ${ }^{2}$ The most memorable moments of The Best Show combined all three qualities at once, featuring madcap humor about music. "Rock, Rot \& Rule", the sketch that inaugurated the show years before its official launch, contained the key ingredients for the show's identity. The routine, performed over the phone like most of The Best Show's interactions, was a preview or rough draft of the form and content that would come to define the comedy of Scharpling and his collaborator, musician/ comedian Jon Wurster.

On 19 November 1997, Scharpling interviewed Ronald Thomas Clontle, author of a book titled Rock, Rot \& Rule. Clontle calls Rock, Rot \& Rule "the ultimate argument settler," whose function is to categorize popular music into acts that rock, acts that rot, and acts that rule. His critical acumen, gleaned by talking to friends in Florida and Kansas, consists entirely of putting musicians into one of these three columns. The irony of Clontle's claim to settle arguments is that his interview has the opposite effect. It infuriates listeners. Impassioned music enthusiasts call in to criticize his methodology, but he cannot be bothered.

4 Unbeknownst to listeners, Clontle is a character played by Wurster. He and Scharpling have intricately scripted their interaction, creating a comedy of outrage among people who take music seriously. And therein lies the value of "Rock, Rot \& Rule" as an influential instance of brevity in humor. Clontle's attention span is short. His method is 
preposterously undercooked. His defense of that method is inarticulate. He denies individualism, defending his conclusions by citing public opinion. His overstatements are both comically to-the-point and incisive in exposing the potential for eternal argument-a hell of the critic's own making, but one in which only his critics simmer and suffer.

Clontle is a character that appeared in the relatively early years of the Internet's democratization of production, consumption, and reception. Yet his characterization is highly prescient with regard to the way in which the Internet has transformed the means and meanings of criticism. In Clontle, Scharpling and Wurster predict and anthropomorphize the deadlocking rhetoric of criticism that arises when information and opinion proliferate outside of traditional measures and loci of proficiency and perception. In this essay I explore the ways in which Clontle's reductive criticism humorously engages with the dilemma of assigning value to art, the behaviors and biases of the critic and the listener, and the circularity of criticism in the Internet age.

Within the double act of The Best Show, Scharpling was the more consistent straight man to Wurster's revolving series of outlandish characters. The host/caller relationship was an ideal platform for Scharpling and Wurster's style of comedy. As the host, Scharpling pretended to be in control, encouraging good taste and restraint. As the caller, Wurster exhibited a darkly comic defiance of that taste and restraint. Over the years, several of the phone calls between the two included (or concluded with) threats of violence directed at Scharpling from a Wurster character. That none of this was visible to the audience allowed the absurd interactions to grow limitlessly within the imaginations of listeners.

7 The fundamental joke at the center of the satirical "Rock, Rot \& Rule" is to torpedo the tendency of contemporary music criticism to force hard categories of judgment for content that demands larger contexts and provokes strong expressions of subjectivity and personal taste. "Rock, Rot \& Rule" preceded the ascendancy of Pitchfork Media, Rotten Tomatoes and Metacritic. Yet those publications' elevation of the numerical score or percentage rating above the textual bases for the numbers has ushered in the kind of critical landscape "Rock, Rot \& Rule" sought to ridicule.

"Rock, Rot \& Rule" is an influential instance of brevity in humor because Clontle's terse system and manner settle nothing. There is an enormous incongruity between his claim to have finished the conversation about music and the effects of that claim. In "The Nature of Critical Argument" from Aesthetics: Problems in the Philosophy of Criticism, Monroe Beardsley address the "problem" of interpreting "'good' and 'bad' in [...] aesthetic contexts," asserting that one way to understand the meaning of valuation is to examine "what critics actually mean when they use their value-terms, what definitions they would give if pressed, what rules of usage they tacitly follow" (471).

9 Thus to arrive at the meaning of any individual critic's assessment, one could work backward from the evaluation and into the means and methods that produced it. ${ }^{4}$ Three minutes into the phone call, Scharpling attempts to interpret Clontle's argument with the following question: "So the book is basically you taking into account the musical scene out there, the whole spectrum of groups and whatnot?" It's a wide-open question, but Clontle responds with a terse "No." He then goes on to describe his 
method, which was to question various friends and acquaintances in Lawrence, Kansas and Gainesville, Florida.

This media file cannot be displayed. Please refer to the online document http:// journals.openedition.org/angles/2118

Clontle repeatedly cites other homegrown sources of opinions in order to shift the burden of defining or defending his argument onto others, as if the critical evaluation/ categorization in his book occurred independently of him. Yet even his most straightforward denial of responsibility for the results, "I'm not a critic, I'm more a compiler of opinions," involves his instrumental part in gathering those opinions toward a specific ranking that communicates a meaning. His deflection cannot erase his essential role.

11 That Clontle's essential role is one that sits outside of traditional sources of opinion or information further complicates his endeavor and its reception by Scharpling and listeners. In "The Authority of Music Criticism," Edward T. Cone identifies and defines these conventional, official authorities: "Just as the reviewer is basically a layman writing for other laymen, and the teacher a practicing musician training other musicians, so the critic is an informed music lover writing for other music lovers" (98). By design, the character Clontle is none of these. He is a layman who doesn't write. Nor is he a teacher or practicing musician. And never once does he seem to love music with any degree of emotional attachment. Additionally, despite publishing a book about popular music for mass cultural consumption, Clontle's endeavor fails to adhere to an inclusive methodology John Richardson has described as "almost an anti-methodology [...] amenable to a large number of theoretical impulses and disciplinary influences" (140).

12 Nevertheless, in addition to addressing Clontle as a critic responsible for the evaluation, Scharpling does try to parse the "definitions" and "rules of usage" involved in his criticism. Again Clontle fails to fully deal with the context of the question and his own culpability, citing "the opinion of the people". He lists acts from each category and justifies the categorization with distinctions that are arbitrary or nonsensical.

13 His list of acts that rock includes Ratt, L7, Nirvana, and Blue Oyster Cult. His list of acts that rule includes the Ramones, Everclear, and Puff Daddy. He concludes that the Beatles merely rock because they "had a lot of bad songs." Scharpling questioningly attempts to comprehend and confirm a framework that appears to collapse on itself one in which a band "can rule without rocking" but "cannot rock without ruling." When asked to distinguish ruling from rocking, Clontle offers circular reasoning that begins and ends with the titular category: "A group that rules just has that extra oomph to push it into the echelon of ruling, of ruler-hood."

14 And at the moment in which this discussion of definitions becomes contentious, Clontle reiterates his description of the book as "the ultimate argument settler". Ten minutes into the call, what was at first a humorously incongruous phrase to promote the book becomes an oppositional phrase, opposite in meaning to the book's effect and antagonistic in its function within the phone call. In light of this disparity, Scharpling asks, "How is it that we're now having an argument over it?" Clontle responds, "That's up to you. The ball's in your court." His prior disavowal of the mechanisms of his critical evaluation is now joined by a denial of his active role in its effects. 

youth, observes that "the drama of how [critics] arrived at their judgments [...] involved two crucial elements" of "expertise" and "taste, or sensibility," which he defines as "the reagent that got you from the knowledge to the judgment". The second quarter of "Rock, Rot \& Rule" penetrates more deeply into Clontle's lack of these characteristics.

17 A couple of throwaway comments earlier in the phone call were inaccurate but uncontested. For example, Clontle called Nirvana's generation-defining hit single "Smells Like Teen Spirit," "It Smells Like Team Spirit." But it is his erroneous assertion that the band Madness "started ska" that provokes the ire of a number of callers who begin to join the conversation. As this is the second act or middle section of the drama Scharpling \& Wurster are creating, the pace of the complications quickens, and Clontle's heedlessness becomes more obvious in his responses to these respondents. His chronic brevity now plays like a symptom of his self-satisfaction and critical detachment. ${ }^{5}$ formed in 1976), Clontle says, "I don't think so." Another caller remarks that Clontle's approach to criticism is causing arguments. Clontle responds, "I disagree one hundred per cent," expertly and humorously conveying Beardsley's "Performatory Theory of critical argument" - "it is not a statement, but an act, it is not true or false, and therefore it cannot be the conclusion of an argument; in other words, it makes no sense to speak of giving reasons to establish its truth" (473).

This media file cannot be displayed. Please refer to the online document http:// journals.openedition.org/angles/2118

layers of satirical meaning are numerous in Wurster's performance of a critic who is only interested in the act of concluding arguments, never constructing them. By declaring, "I disagree one hundred per cent," he is performing a response that would undo his own argument if he bothered to acknowledge the validity of the evaluation by others of his act of evaluation. The routine starts to resemble an ouroboros that repeats but never progresses. As one might imagine, this enrages unsuspecting listeners.

A particularly well-informed caller, whose expertise on the subject of ska would befit a critic (though she never refers to herself as one), urges Clontle to study the history of music. She recommends writers, such as Ira A. Robbins of the Trouser Press Record Guide, as thorough researchers from whom Clontle could learn. She gives an impassioned monologue on the importance of research, to which Clontle responds, "It's too late. It's already coming out. And I stand by every sentence in this book."

Clontle baits her in many other ways, but it is his refusal to learn or be informed, and his performance of that refusal, that characterizes him as antithetical to experts. Though he admits that a little of his own personal taste informs the rankings, he never expands on these tastes, beyond a blunt preference for acts with guitars and a low 
opinion of pianos. And his defense of the book's "sentences" is itself baseless as the book consists of lists, not sentences and paragraphs.

What emerge in the third quarter of the call are listeners whose comparative expertise and well-honed tastes highlight the failures of this caricature of an everyman / establishment critic. By treating the existence and impending publication of his book as the destination for any conversation about music, Clontle acts as if he were free to ignore facts, to ignore history, and to ignore the role that taste plays in acquainting listeners with music and informing their judgments. In contrast, these callers are like Sir Donald Tovey's "ideal listener [...] not necessarily trained in music, but endowed with a willing ear to accept a musical experience and examine the results" (Rich 221-2).

The culmination or cumulative meaning of a Best Show call is often a partial or full redefinition of the caller. Scharpling and Wurster are masters of the comic reversal and employ it as a dramatist would, to permanent effect within the narrative. One of the other highlights of their repertoire is "The Springsteen Book" from 2010. In this call, Wurster plays a Bruce Springsteen biographer who shares previously undisclosed details about the career of the rock star. Though a slight amount of the musical commentary is plausible, the call is, for the most part, an increasingly ridiculous portrait of Springsteen as a man obsessed with earning a living and preserving his bluecollar credibility.

This media file cannot be displayed. Please refer to the online document http:// journals.openedition.org/angles/2118

The reversal near the end of the call reveals the scholar to be a plumber who happened to pick up the phone and make up nonsense about Springsteen for nearly an hour. Afterwards, the "real" author joins the line for a few minutes, but he bores Scharpling so much that the host asks him to put the plumber back on the phone. When interviewed about the call for The Best of the Best Show, a retrospective box set issued in 2015 by Numero Group, Scharpling commented, "while trashy gossip-based rock books aren't my favorite, they are a million times better than an egghead book about rock" (90).

A call like "The Springsteen Book" allows us to understand another significant satirical thread of "Rock, Rot \& Rule." It's easy to diagnose the problems of Clontle's approach to music criticism, which is woefully uniformed on most counts when judged by professional standards. And in its ordinariness, his criticism typifies a common man's way of responding to art. This is a quality that places "Rock, Rot \& Rule" ahead of its time relative to the ubiquity of ordinary, unchecked critics online. The contemporary everyday critic is defined by his lack of expertise. To demand his credentials is ultimately pointless. Social media's encouragement of instinctive, commentary-free votes and likes and other affirmations has operationalized the cultivation of taste that requires little knowledge beyond the object being reacted to in the moment.

The plumber/expert of "The Springsteen Book" could be compared and contrasted to clontle in this respect. His yarns about Springsteen are pure fiction, bereft of knowledge, and he uses words like "absolutely," "yeah," and "sure" to react to 
Scharpling's questions about these stories. The brevity at the center of "The Springsteen Book" is that of an imaginative alternative history that could include anything and go anywhere. It is accommodating and thus avoids argument.

The agreeable plumber's brevity is positive and affirmative, which differs in value from Clontle's readiness to say no and disagree. Both present information as fact. Neither feels a responsibility to support those facts with reliable contexts. Clontle's assertions of impartiality are particularly ironic, as his conclusions are predicated on subjectivities so ingrained that they are thoroughly unexamined. We could consider Roger Parker's connection of official history to fact in order to better understand this fundamental contradiction within Clontle.

Our musicologist past over the last fifty or so years has been punctuated by exhortations that present themselves as unproblematic, as a 'common-sense' view: 'just' attend to the facts; 'just' listen to the music. Perhaps the covert ideology nesting in that small word 'just' has by now been sufficiently exposed. (Parker 9)

Many of the professional class of critics that Scharpling describes as "egghead[s]" hold to neither the plumber's positivity nor Clontle's negativity but to the ideal of justness. While the publications that result from a commitment to justness are more accurate by some measures, "that small word" provides cover for any number of accusations one could make about the publications. In this way, Clontle is evocative of the establishment critic. He just happens to be a lot more fun than they are because he exists within a send-up of music criticism.

The turn within the final section of "Rock, Rot \& Rule" is not as sharp as that of "The Springsteen Book." That is to say, Clontle is not revealed to be an impersonator. Consistent with all of the calls that will follow in the Scharpling and Wurster phonography, Wurster doesn't break character and reveal himself. However, the contentious conversations with callers that take place in the third quarter of the call transition into an implicit defense or validation of Clontle's place within the culture of commentary.

They may be "ideal listeners," but many of these callers reveal biases or weaknesses that undo their own arguments against this "argument settler." Several of them criticize Clontle's research locations, as if Kansas and Florida couldn't possibly be representative of tastes in popular music. This assumption of insufficiency or provinciality, which holds that New York City is necessarily better than Lawrence, Kansas for assessing public tastes, is as fallacious as anything Clontle asserts. That Clontle is a fiction and the callers are real indicts the callers, whose true colors emerge in reaction to an act.

31 Callers also react with curiosity, providing their own lists of groups not yet mentioned and soliciting Clontle's ratings for those groups. The impetus for these solicitations might be to have a laugh or to test the critic's audacity. Nevertheless the callers are seeking his opinion, and by doing so substantiate his status as an authority. In fact, the call ends with an outright declaration of vindication. A caller corrects Clontle's claim that Stereolab didn't use guitars, and the critic counters that "Time will vindicate me." Logically speaking, short of a remix or rerecording, time could not remove guitars from songs that contained them and somehow retroactively vindicate Clontle's erroneous 
claim. But he never once builds his arguments on logic, so why start now? As he has already stated, "It's too late." The book deal is done. That much is true.

Clontle's willful ignorance of historical circumstances and simultaneous belief in time as a vindicator add yet another subtle strand to the routine's playfulness concerning arguments in aesthetic studies. Musician David Byrne, pushing back against the "absolute nonsense" advocated by critics and thinkers like Clive Bell and David Hume, summarizes their belief in the timelessness of "great" works of art in the following manner: "The implication is that great work should, if it is truly great, not be of its time or place. We should not be aware of how, why, or when it was conceived, received, marketed or sold. It floats free of this mundane world, transcendent and ethereal" (Byrne 277). Byrne asserts that, as with the writings of Shakespeare, time often makes a difference in the way art is evaluated. Clontle is no great critic or thinker or practitioner, but his contradictory positions on temporality convey the whole spectrum of its importance to cultural and critical reception. By both rejecting and embracing time as a key factor in reception, Clontle synthesizes Bell and Byrne.

Scharpling comes to Clontle's defense when an agitated caller joins the conversation to question the critic's role as an arbiter of taste. The host compares those who disagree with Clontle to disgruntled listeners of the radio station: "We get this argument with WFMU a lot [...] if you don't like it, you could just turn it off, go off the dial and see if there's something else you're interested in. If you're not interested in this, I guess you could buy another rock book."

This media file cannot be displayed. Please refer to the online document http:// journals.openedition.org/angles/2118

The natural extension of Scharpling's argument is that those moved to anger over the critical space Clontle occupies could not only buy another book, but could become critics themselves. Perhaps the most prescient aspect of "Rock, Rot \& Rule" is its performative foreshadowing of the relationship between individuality and universality in the Internet age. Clontle embodies this relationship because he is in the act of making universal claims universally available, but steadfastly denies the subjective undercurrents of those claims.

This conflict is pertinent to the history of music because "in the earlier periods of the history of music, universality was something demanded of the musician. He had no right to follow his inclinations or his impulses" and yet "new music" threatens to "[appear] [...] without predetermined concepts, divorced from contact with the past" (Einstein 328-331). The dilemma Einstein describes as being true for the modern musician is shared by anyone attempting to respond to modern music, especially those who use the Internet to publish their responses.

So the contemporary question is not whether universality is possible. In terms of dissemination of musical content and critical thought pertaining to it, universality has been achieved (or as Clontle might say, "settled.") Virtually anyone, anywhere, could participate in the acts of creation and criticism. Yet this vast global connection does not necessarily encourage a universal culture of art appreciation. The proliferation of blogs and other individual forms of criticism is the fulfillment of Einstein's identified/ prophesied "period of negation, of tangential music" (331). Scharpling's advice to "buy 
another rock book" (find another source) is infinitely sustainable, but the sheer number of options creates more tangents and fewer consensuses.

Hence the Internet has not proven to be an ultimate argument settler. Mendelsohn writes with concern about "the unprecedented explosion of personal writing (and inaccuracy and falsehood) online, in Web sites and blogs and anonymous commentary -forums where there are no editors and fact-checkers and publishers to point an accusing finger at". Nearly twenty years after the call that spoke him into being, Ronald Thomas Clontle is an avatar of the sort of anxiety Mendelsohn describes. By bridging the pretense of the establishment critic with the irresponsible disengagement of the rank amateur, Clontle exposes problems of universality and individuality.

"Rock, Rot \& Rule" are the three little words that Scharpling and Wurster chose to use for their own satirical argument about judgment in popular culture. From a comic standpoint, their brevity is endlessly rewarding, because these small words prompt longwinded responses that in turn receive only these small words. To contextualize Clontle within a contemporary Internet meme, he was an Obvious Troll before the language and sensibilities existed to identify him as such (i.e. Obvious Troll is Obvious, a verbally representational ouroboros). It's telling that the Internet has caught up with Clontle by proving and certainly not "settling" the problem of circular reasoning he embodies. Time has indeed vindicated Ronald Thomas Clontle.

\section{BIBLIOGRAPHY}

Beardsley, Monroe C. Aesthetics: Problems in the Philosophy of Criticism. New York: Harcourt, Brace \& World, Inc., 1958.

Byrne, David. How Music Works. San Francisco: McSweeney's, 2012.

Cone, Edward T. Music: A View from Delft. Ed. Robert P. Morgan. Chicago: U. of Chicago P., 1989.

Einstein, Alfred. "Universality and Music Today." The Attentive Listener: Three Centuries of Music Criticism. Ed. Harry Haskell. Princeton, Princeton UP, 1996. 328-331.

Mendelsohn, Daniel. “A Critic's Manifesto.” The New Yorker, August 28, 2012 https:// www.newyorker.com/books/page-turner/a-critics-manifesto

Parker, Roger. "Introduction: On Reading Critics Reading." Reading Critics Reading: Opera and Ballet Criticism in France from the Revolution to 1848. Ed. Roger Parker and Mary Ann Smart, New York, Oxford UP, 2001. 1-9.

Rich, Alan. So I've Heard: Notes from a Migratory Music Critic. Pompton Plains, Amadeus Press, 2006.

Richardson, John. "On Music Criticism and Affect: Two Instances of the Disaffected Acoustic Imaginary." Critical Musicological Reflections: Essays in Honour of Derek B. Scott. Ed. Stan Hawkins. Farnham: Ashgate, 2012.139-158. 
Scharpling, Tom and Jon Wurster. The Best of the Best Show. Chicago, Numero Group, 2015.

\section{NOTES}

1. Archives of the show are available at https://wfmu.org/playlists/BS.

2. Scharpling continues to use this promotional phrase at the revived version of his show at http://thebestshow.net.

3. This recording and others referenced and quoted in this essay are collected in Numero Group's 2015 box set The Best of the Best Show.

4. Beardsley also asks a "second question" about what can possibly be known or meant through reason and objectivity within the activity of "critical evaluation," though that philosophical framework is not as pertinent as the first question to the content of the present essay.

5. As if to exaggerate this detachment to the extreme, Wurster adds distractedness to Clontle's comportment within the action of the phone call. He loses track of the conversation because he's preoccupied with a basketball game which is on in the background.

\section{ABSTRACTS}

Tom Scharpling was the longtime host (October 2000 - December 2013) of The Best Show on WFMU, a music/comedy program that originated on listener-supported New Jersey radio station WFMU and became internationally popular through Internet streaming and podcasting. My paper examines the ways in which "Rock, Rot \& Rule," the sketch that inspired the program, utilizes brevity to satirize the dilemma of criticism. Scharpling interviewed Ronald Thomas clontle, author of a book titled Rock, Rot \& Rule, "the ultimate argument settler," whose function is to categorize popular music into acts that rock, acts that rot, and acts that rule. The premise of Clontle's book involves comedic devices like overstatement and simplification. The irony of Clontle's claim to settle arguments is that his interview has the opposite effect. It infuriates listeners. Impassioned music enthusiasts call in to criticize his methodology, but he cannot be bothered. Unbeknownst to listeners, Clontle is a character played by musician Jon Wurster. He and Scharpling have intricately scripted their interaction, creating a comedy of outrage among people who take music seriously. And therein lies the value of "Rock, Rot \& Rule" as an influential instance of brevity in humor. For the unsuspecting listeners of "Rock, Rot \& Rule," Clontle arouses anxiety because he is indicative of the future of criticism.

Tom Scharpling a longtemps animé The Best Show on WFMU (entre octobre 2000 et décembre 2013), émission musicale/humoristique qui a débuté sur la chaîne de radio WFMU du New Jersey, avant de devenir célèbre dans le monde entier grâce au streaming et aux podcasts. Cette contribution étudie comment « Rock, Rot and Rule », le sketch qui a inspiré l'émission, exploite la forme courte pour proposer une satire de la critique musicale. Dans l'émission, Scharpling interviewe Ronald Thomas Clontle, auteur d'un libre intitulé Rock, Rot and Rule, The ultimate argument settler, dont l'objet est de classer la musique populaire en morceaux qui " déchirent » (rock), qui sont «pourris » (rot) ou qui « en imposent» (rule). Le livre exploite des techniques de la comédie comme l'exagération et la simplification. Clontle prétend résoudre les conflits mais son interview a l'effet inverse. Elle rend les auditeurs furieux. Les amateurs passionnés de 
musique appellent la radio pour critiquer sa méthodologie mais Clontle n'en a cure. Ce qu'ignorent les auditeurs, c'est que Clontle est en réalité un personnage joué par le musicien Jon Wurster. Scharpling et lui ont préparé leur échange soi-disant impromptu, provoquant un faux scandale pour tous ceux qui prennent la musique au sérieux. C'est là que réside l'intérêt de «Rock, Rot and Rule », exemple célèbre de l'humour sous sa forme brève. Clontle provoque l'angoisse chez les auditeurs qui ne se doutent de rien, et il anticipe ainsi l'avenir de la critique.

\section{INDEX}

Keywords: podcasting, radio, internet, Scharpling Tom, Wurster Jon, Best Show on WFMU (The), humour, interaction, interview, music

Mots-clés: podcasting, radio, internet, Scharpling Tom, Wurster Jon, Best Show on WFMU (The), humour, interaction, interview, musique

\section{AUTHOR}

\section{THOMAS BRITT}

Thomas Britt has been at George Mason University since 2007, when he was hired as the first fulltime faculty member of the Film and Video Studies program. His documentaries and music videos have screened internationally. His essays on film and popular music are available in edited volumes and print and online journals. PopMatters publishes "On Principle", his column about media ethics. Contact: tbritt [at] gmu.edu 